Acta Horticulturae et Regiotecturae - Special Issue

Nitra, Slovaca Universitas Agriculturae Nitriae, 2016, pp. 8-12

\title{
THE DYNAMICS OF CHANGES IN NUTRITIONALLY SIGNIFICANT INGREDIENTS OF CARROT JUICE AFTER THE PASTEURIZATION
}

\author{
Andrea MENDELOVÁ1*, L’ubomír MENDEL ${ }^{2}$, MARTINA FIKSELOVÁ', Alena ANDREJIOVÁ ${ }^{1}$ \\ 'Slovak University of Agriculture in Nitra, Slovak Republic \\ ${ }^{2}$ National Agricultural and Food Centre Research Institute of Plant Production, Pieštany, Slovak Republic
}

\begin{abstract}
Carrot (Daucus carota L.) belongs to the most common type of vegetable because of its consumption, versatile usage in the canning industry and because of its beneficial effects on the health of consumers. It is valuable mainly because of the high content of $\beta$-carotene, B vitamins, vitamin C, carbohydrates and minerals. The aim of this work was to compare the quality of carrot juice from different varieties of carrots regarding the content of total carotenoids and polyphenols and also to assess the dynamics of their changes evaluated under the influence of the pasteurization $\left(85^{\circ} \mathrm{C}\right)$. There were selected varieties of carrot such as Baltimore F1, Exhibition F1, Kamaran F1, Napoli F1, Belgrado F1, Komarno F1, Nantes, Rubina and Nandrin F1. The highest content of carotenoids, assessed by the spectrophotometry, was determined in variety Kamaran F1 (213.66 mg $100 \mathrm{~g}^{-1}$ dry matter) and the lowest in Belgrado F1 (146.80 mg $100 \mathrm{~g} \mathrm{~g}^{-1}$ dry matter). After the pasteurization, the content of carotenoid decreased and ranged

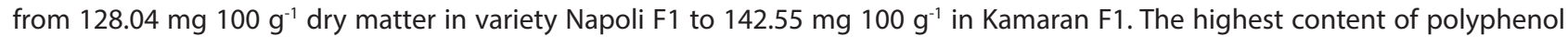
determined by the Folin Ciocalteu method was found in fresh juice of Rubina (922.80 mg GAE $100 \mathrm{~g} \mathrm{~g}^{-1}$ dry matter) and the lowest in the variety Nantes $\left(535.75 \mathrm{mg} \mathrm{GAE} 100 \mathrm{~g}^{-1}\right.$ dry matter). After the pasteurization, the content of the monitored components was found to be 450.34 mg GAE $100 \mathrm{~g}^{-1}$ dry matter in Napoli F1 to 751.95 mg GAE $100 \mathrm{~g}^{-1}$ dry matter in Komarno F1 variety.
\end{abstract}

Keywords: carrot, juice, carotenoids, polyphenols

Carrot (Daucus carota L.) is one of the popular root vegetables grown throughout the world and it is the most important source of dietary carotenoids (Sharma et al., 2012). In recent years, worldwide consumption of carrots has been steadily increasing because of their nutritional benefits ( $Y u$, Zhou and Parry, 2005). Carrots have been shown to have other potentially beneficial health effects, anti-carcinogenic, antioxidant, and immune-boosting properties, as well as the pro-vitamin A activity of some carotenoids all of these add to their importance in the diet (Jintasataporn, 2012). Krinsky and Johnson (2005) state that carrots and their fresh products (shredded carrots, sliced carrots and carrot juice) may protect humans against certain types of cancer and cardiovascular diseases.

The organoleptic (taste) qualities of carrot are controlled by a balance between the range of compounds including both, reducing and non-reducing sugars (Simon et al., 1989) and the research indicates that sweetness is an important factor in the acceptance of new commercial vegetable cultivars (Nookaraju et al., 2010). Carbohydrates can make up almost $75 \%$ of the dry matter of carrot roots (Arscott and Tanumihardjo, 2010). The main soluble sugars in carrots are glucose, fructose, and sucrose, with sucrose in major ratio. In carrot root the accumulation of hexoses predominates during the early part while sucrose accumulates during the second half of the growing period (Bufler, 2013).

The nutritional value of fruit and vegetable is often associated with their antioxidant capacities (Sing et al., 2009).
Carrot is a good source of natural antioxidants, especially carotenoids and phenolic compounds (Chantaro et al., 2008; Leja et al., 2013; Šlosár et al., 2013). Phenolic compounds account for the major portion of the antioxidant capacity in many plants. Carrots have been ranked $10^{\text {th }}$ among 39 fruits and vegetables in nutritional value and the research on carrot health benefits still continues (Sun et al., 2012).

The presence of phenolic compounds in carrots contributes to their sensory qualities, like colour (Zhang and Hamauzu, 2004), bitterness or aroma (Kreutzmann et al., 2008). Therefore, the phenolic compounds could be used as a good indicator to evaluate the vegetables quality during processing and storage (Goncalves et al., 2010). Major phenols in carrots include chlorogenic, caffeic and p-hydroxybenzoic acids along with numerous cinnamic acid derivatives (Wang et al., 2006).

The biosynthesis of carotenoids in plants is well understood. This also applies to carrot which is an important crop in relation to carotenoids due to high concentration (28 mg $100 \mathrm{~g}^{-1}$ ) accumulated in the tissue (Surles et al., 2004). The most abundant carotenoid in orange carrots is $\beta$-carotene $(45-80 \%)$, and there can be found smaller fractions of $\alpha$-carotene and lutein (Oliveira et al., 2010).

The aim of this work was to analyse the quality of carrot juice in order to assess the impact of the pasteurization on changes in the content of total polyphenols and carotenoids. 


\section{Material and methods}

Within an experiment, following 9 varieties of carrot (Daucus carota L.) were used: Baltimore F1, Exhibition F1, Kamaran F1, Napoli F1, Belgrado F1, Komarno F1, Nantes, Rubina and Nandrin F1. Biological material was cultivated in the botanical garden of the Slovak University of Agriculture in Nitra in 2014. Area is situated in very warm agro-climatic region, very dry sub-region. The average annual temperature is $10{ }^{\circ} \mathrm{C}$. The average annual rainfall is $584.5 \mathrm{~mm}$ and the average rainfall for the growing season is $287.5 \mathrm{~mm}$. In terms of soil characteristics, soil is a glue fluvisol formed on alluvial sediments.

Roots of the selected varieties were collected at the stage when they were fully matured, suitable for processing and storage. By the cold pressing (the multi-functional juicer Champion 2000), we produced carrot juices which were analyzed in the fresh state and after the pasteurization, performed at $85^{\circ} \mathrm{C}$ for 5 minutes.

Total carotenoid content was performed spectrophotometrically, by the Jenway device Model 6405 UV/VIS, according to the methodology given by STN 12136 - Determination of total carotenoids and individual carotenoid fractions. The homogenized samples were kept in acetone to extract carotenoids and then they were collected in the petroleum solution. The absorbance of carotenoids was measured at a wavelength of $450 \mathrm{~nm}$. Carotenoid content was calculated and expressed as $\beta$-carotene. The determination of the total polyphenol content was performed by the method of Folin - Ciocalteu (Singleton and Rossi, 1965) that is based on the reaction of Folin - Ciocalteu reagent with polyphenols to form a blue complex. The intensity of the colour is proportional to the content of polyphenols. The evaluation is performed with a spectrophotometer at a wavelength of $700 \mathrm{~nm}$. Polyphenol content was expressed in mg GAE 100 $\mathrm{g}^{-1}$ (gallic acid equivalent).

The content of total polyphenols and carotenoids was expressed in dry matter of juice that was determined by the gravimetric method at $105^{\circ} \mathrm{C}$. The results of the analysis were processed by the statistical program Statistica 8.0 (StatSoft Inc., Tulsa, USA). The differences among the samples were observed by the Fisher's LSD test and the effect of pasteurization on polyphenol and carotenoid content by the Multifactor analysis of variance.

\section{Results and discussion}

In the fresh carrot juice there was determined the content of total carotenoids expressed as $\beta$-carotene in the average values from $146.80 \mathrm{mg}$ $100 \mathrm{~g}^{-1} \mathrm{DM} \mathrm{mg} 100$ to $213.66 \mathrm{mg}$ $100 \mathrm{~g}^{-1}$ DM (Figure 1). Statistically significantly the highest content of carotenoids was found in the juice of Kamaran F1 and the lowest in Belgrado F1. Carotenoid content higher than $200 \mathrm{mg} 100 \mathrm{~g} \mathrm{~g}^{-1}$ was observed in the group of varieties Napoli F1, Rubina, Exhibition $\mathrm{F} 1$; among them, no statistically significant difference at $p \leq 0.05$ was determined. The average content of carotenoids showed varieties Komarno F1, Nantes and Baltimore F1 which created a separate homogeneous group. Minimum content of carotenoids was found in variety Belgrado F1.

After the pasteurization, in all varieties the total carotenoid content decreased. Carotenoids in carrot juice after the pasteurization ranged from $128.04 \mathrm{mg} 100 \mathrm{~g}^{-1} \mathrm{DM}$ in Napoli F1 to
$142.55 \mathrm{mg} 100 \mathrm{~g}^{-1} \mathrm{DM}$ in Kamaran F1. The most significant decrease was observed at variety Napoli F1 and the lowest in variety Belgrado F1. In percentage, the decrease in total carotenoids was detected from $9.14 \%$ in Belgrado variety $\mathrm{F} 1$ to $37.03 \%$ in Napoli F1. Higher carotenoid content decrease was recorded also in varieties Exhibition (by 35.03\%), Rubina (by $34.41 \%$ ) and Kamaran F1 (by 33.28\%). At varieties of Nandrin F1, Komarno F1 and Baltimore F1 the decrease in carotenoid content was from 20 to $25 \%$. By the statistical processing of collected data on carotenoid content in fresh carrot juice and carrot juice after the pasteurization, we have found that the change in the content of carotenoids that occurred after treatment is statistically significant at $p \leq 0.05$ (Figure 2).

Baranski et al. (2010) performed an analysis that was aimed to assess the content of carotenoids in carrots of different varieties around the world. The authors state the carotenoid content from 0 to $40 \mathrm{mg} 100 \mathrm{~g}^{-1}$ fresh matter. Carrot varieties of European origin, on average, contained more carotenoids than varieties of Asian origin. In the orange varieties authors reported average value $9.3 \mathrm{mg} 100 \mathrm{~g}^{-1}$ carotenoids. Compared to our results, we can state that they correspond to these results. In our work we observed values from $6.99 \mathrm{mg} 100 \mathrm{~g}^{-1}$

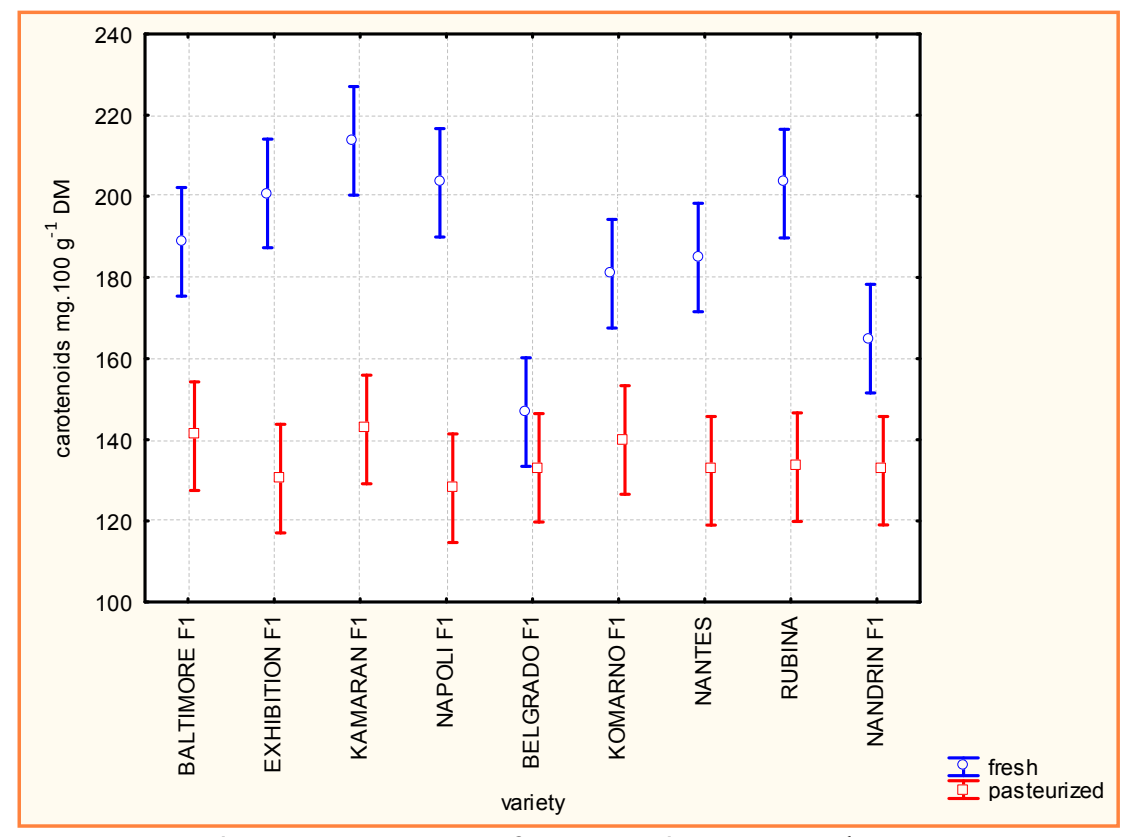

Figure 1 The average content of carotenoids (mg $\left.100 \mathrm{~g}^{-1} \mathrm{DM}\right)$ in carrot juice before and after the pasteurization 


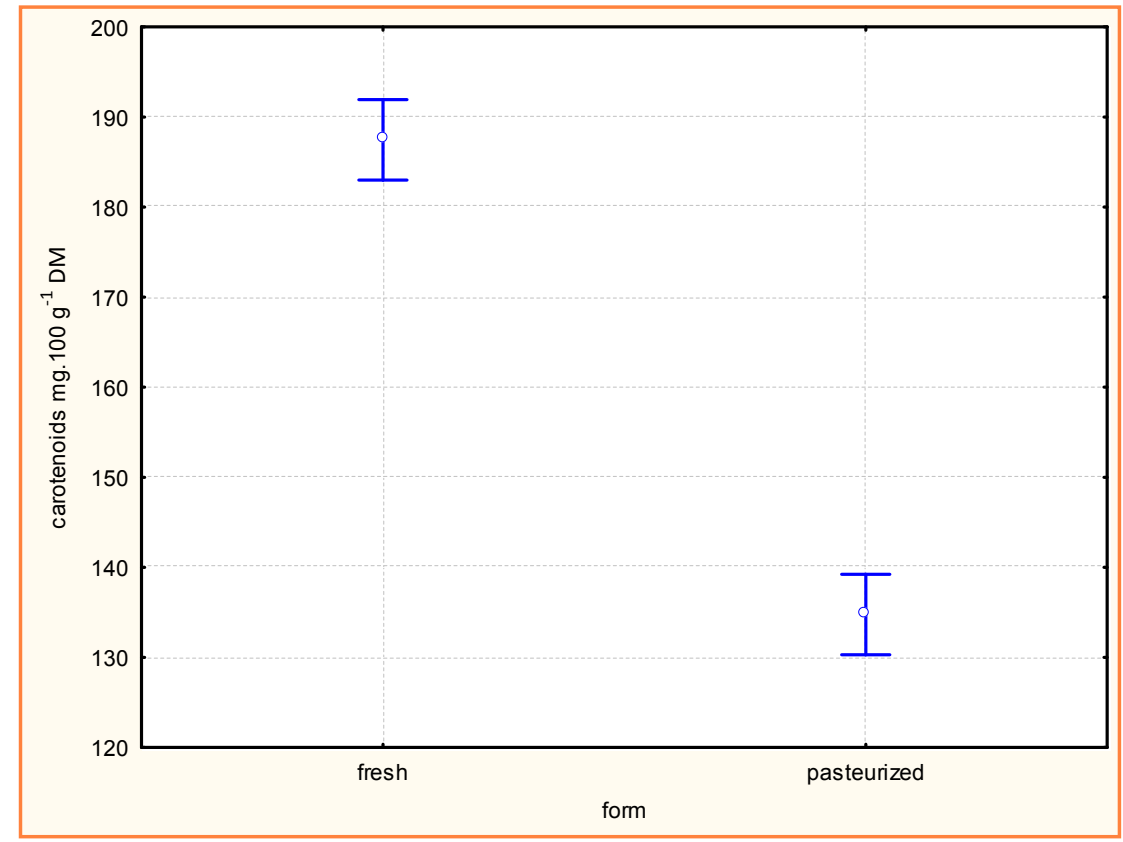

Figure 2 Comparison of average content of carotenoids ( $m g 100 \mathrm{~g}^{-1} \mathrm{DM}$ ) in carrot juice before and after the pasteurization

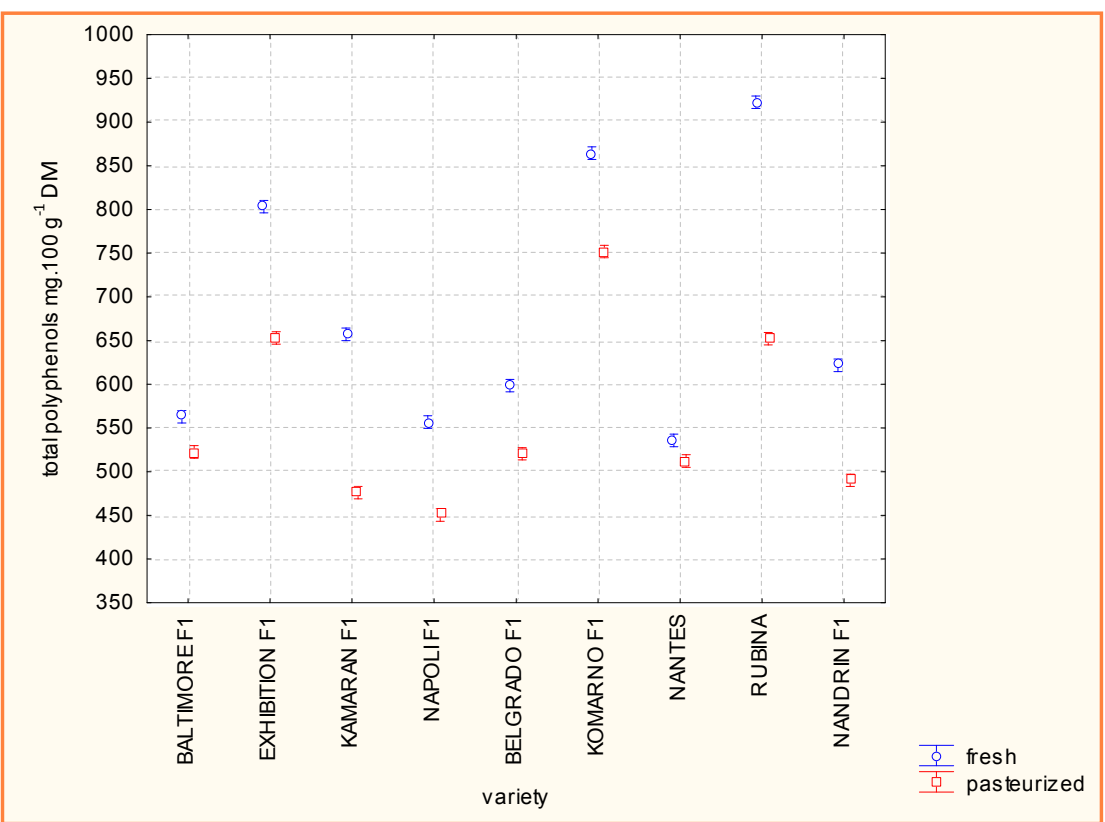

Figure 3 The average content of total polyphenols ( $\mathrm{mg} 100 \mathrm{~g}^{-1} \mathrm{DM}$ ) in carrot juice before and after the pasteurization

fresh matter in variety Belgrado F1 to $17.52 \mathrm{mg} 100 \mathrm{~g}^{-1}$ fresh matter in variety Kamaran F1.

Frančáková et al. (2006) examined the content of carotenes in 5 varieties of carrot (Napa F1, Nevis F1, Kathmandu F1, Florida F1, Idaho F1) cultivated in three locations (Nitra, Prusy, Komarno). The lowest content of carotenoids

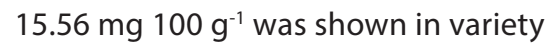
Napa F1 and its lowest content, by comparison to other varieties, was
Chen et al. (1995) performed an analysis aimed at the stability of carotenoids and provitamin A in carrot juice during storage. Carrot juice has been pasteurized and then stored at 4.25 and $35{ }^{\circ} \mathrm{C}$ for 3 months. The results show decrease in amount of lutein, $\alpha$-carotene, and $\beta$-carotene in carrot juice with increasing storage temperature.

Salariya et al. (2009) investigated the effect of different blanching media on the nutritional value of carrot juice. The highest protein content $(1.34 \%)$, minerals $(2.5 \%)$ and water-soluble sugars $(5.46 \%)$ were found in carrot juice obtained from carrots blanched in $0.5 \%$ acetic acid and $1 \% \mathrm{CaCl}_{2}$. At the same time, they detected the highest amount of $\beta$-carotene (195 mg $100 \mathrm{~g}^{-1} \mathrm{DM}$ ) and lower content of vitamin C (8 mg $\left.100 \mathrm{~g}^{-1} \mathrm{DM}\right)$ in this juice. In carrot juice with no blanching treatment authors determined lower protein content $(0.88 \%)$, minerals $(1.26 \%)$, soluble sugars $(4.81 \%)$ and the decrease in $\beta$-carotene content (175 mg $\left.100 \mathrm{~g}^{-1} \mathrm{DM}\right)$ while vitamin $\mathrm{C}$ content was higher (44 mg $100 \mathrm{~g}^{-1} \mathrm{DM}$ ).

Bongoni et al. (2014) performed the study in order to find a way how to cook carrot to retain the highest content of $\beta$-carotene and appropriate sensory properties. After 20 minutes of cooking, the amount of $\beta$-carotene decreases by $19 \%$ while at stewing of the carrots it retains higher amount of $\beta$-carotene. The sensory quality of the carrots, treated by both methods, did not differ, but the carrots prepared by steaming showed significantly higher amount of $\beta$-carotene.

The highest content of total polyphenols we found in the juice of variety Rubina $(922.80 \mathrm{mg}$ GAE $\left.100 \mathrm{~g}^{-1} \mathrm{DM}\right)$ and the lowest in Nantes (535.75 mg GAE $100 \mathrm{~g}^{-1} \mathrm{DM}$ ) (Figure 3). Polyphenol content in selected varieties decreased in this order: Rubina $>$ Komarno F1 > Exhibition F1 > Kamaran F1 > Nandrin F1 > Belgrado F1 > Baltimore F1 > Napoli F1 > Nantes. By testing, using the Tukey HSD test, the relative differences among varieties in the content of polyphenols were observed. Statistically significantly we found the highest content of polyphenols $(p \leq 0.05)$ at variety Rubina and the lowest in Nantes. Statistically significant differences were not 


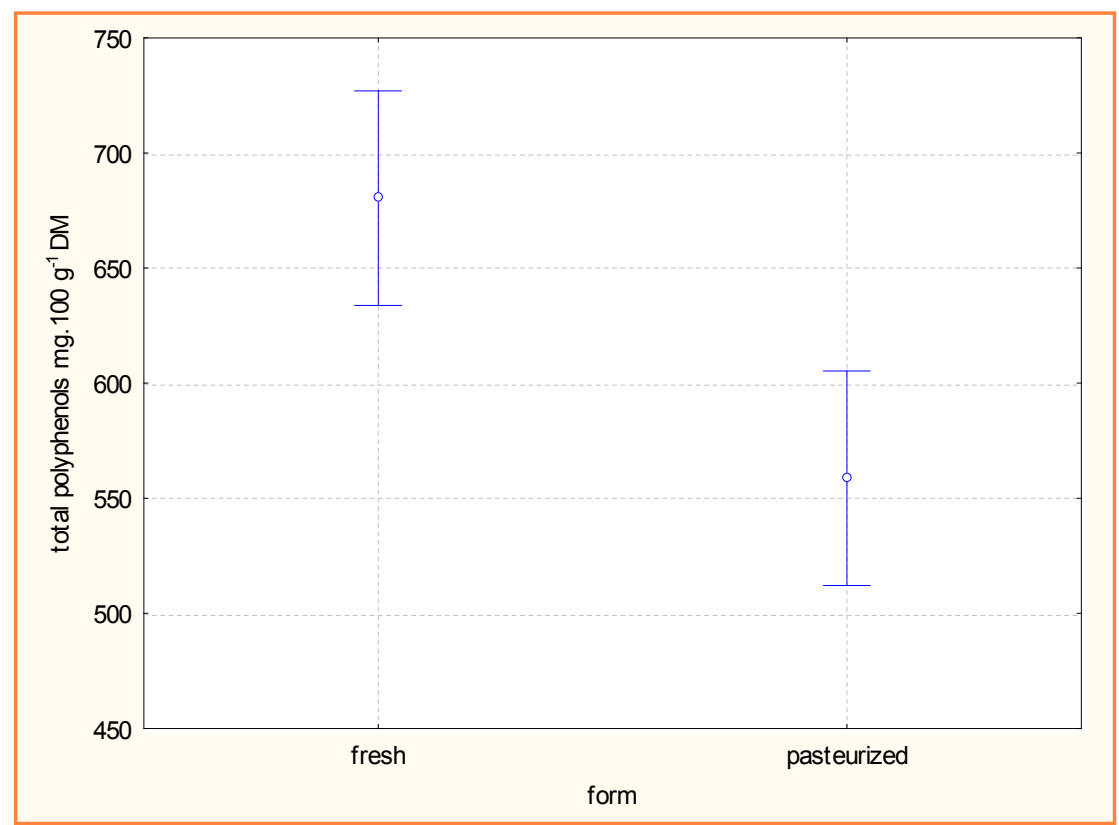

Figure 4 The comparison of average content of total polyphenols ( $\mathrm{mg} 100 \mathrm{~g}^{-1}$ $\mathrm{DM}$ ) in carrot juice before and after the pasteurization

detected in combination of varieties: Napoli F1 - Baltimore F1, Baltimore F1 - Begrado F1, Napoli F1 - Belgrado F1, Belgrado F1 - Nandrin F1, Nandrin F1 - Kamaran F1.

After the pasteurization, the decreased content of total polyphenols (TPC) was determined. TPC after the pasteurization ranged from $450.34 \mathrm{mg}$ GAE $100 \mathrm{~g}^{-1} \mathrm{DM}$ at Napoli F1 to 751.95 mg GAE $100 \mathrm{~g}^{-1}$ DM in Komarno F1. We observed good stability in varieties Nantes with a decrease by $4.39 \%$ in TPC and in Baltimore F1 in which the decrease was $7.17 \%$. In variety Rubina the content of total polyphenols decreased by $29.34 \%$ and in Kamaran F1 by $27.57 \%$.

By the multi-factorial analysis of variance, we were able to confirm ( $p \leq 0.05)$ statistically significant higher polyphenol content in fresh juice than in juice after the pasteurization.

Cieślik et al. (2006) monitored polyphenols in fruits and vegetables. In the fresh carrots they determined the average value of polyphenols 156 mg $100 \mathrm{~g}^{-1}$. In the dry matter there was average of polyphenol content detected to be $1485 \mathrm{mg} 100 \mathrm{~g}^{-1}$. At the same time they indicated the polyphenol content in the dry matter

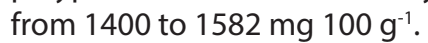

Tian et al. (2014) investigated the effect of blanching and pasteurization on polyphenols and antioxidant activity of carrot juice. They reported that blanching has no significant impact on the total content of polyphenols and antioxidant activity. Negative impact on total polyphenol content and antioxidant activity was detected at pasteurization of carrot juice and there was found decrease in both observed indicators. These results are similar with ours; in our case, decreasing in total polyphenol content after the pasteurization of carrot juice was monitored as well.

Jabbar et al. (2014) examined the combined effects of ultrasound and high hydrostatic pressure on the total polyphenol content in carrot juice. The carrot juice was subjected at room temperature to ultrasonication $(20 \mathrm{kHz})$ and pressure $(250,350$, $450 \mathrm{MPa}$ ) for 10 minutes. Under the ultrasonic treatment at power of $20 \mathrm{kHz}$ and pressure of $450 \mathrm{MPa}$, the total polyphenol content of carrot juice significantly increased. They stated that under these conditions the overall quality of carrot juice has improved.

Teixeira (2009) examined the effect of storage on the content of anthocyanin dyes, polyphenols and antioxidant capacity of carrot juice from purple carrots. The authors reported that after 107 days of storage at $4,20,35{ }^{\circ} \mathrm{C}$, polyphenols decreased by $20 \%$ at all temperatures. Anthocyanin degradation occurred during storage at $4{ }^{\circ} \mathrm{C}$ and at $35^{\circ} \mathrm{C}$ it decreased by $50 \%$.
Kramer et al. (2012) examined the polyphenol content of 10 different coloured varieties of carrots. Purple varieties contained polyphenols in significantly higher amounts than the yellow, orange and red varieties. Polyphenol content in purple varieties ranged from 4113 to $11737 \mathrm{mg} \mathrm{kg}^{-1}$ DM. Other varieties were characterised by lower content of polyphenols, ranging from 33 to $1369 \mathrm{mg} \mathrm{kg}^{-1} \mathrm{DM}$.

Grassmann et al. (2007) compared the content of polyphenols in five varieties of carrots, included orange, white, yellow, red and purple. The authors concluded that the varieties with purple carrot roots contain higher polyphenol content compared to the others.

Augspole et al. (2012) monitored the polyphenol content in 5 varieties of hybrid carrot Forto, Bolero, Maestro, Berlikum, Champion in fresh matter after 5 months of storage. Before storing, the authors found polyphenols in range from $271.21 \mathrm{mg}$ GAE $100 \mathrm{~g}^{-1} \mathrm{DM}$ (Bolero) to $539.76 \mathrm{mg}$ GAE $100 \mathrm{~g}^{-1}$ DM (Forto). After storage, there was detected the decrease of the polyphenols from $241.26 \mathrm{mg} \mathrm{GAE}$ $100 \mathrm{~g}^{-1} \mathrm{DM}$ (Bolero) to $395.35 \mathrm{mg} \mathrm{GAE}$ $100 \mathrm{~g}^{-1} \mathrm{DM}$ (Forto).

\section{Conclusion}

Total carotenoid content in unpasteurized juice was detected from

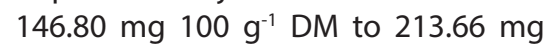
$100 \mathrm{~g}^{-1} \mathrm{DM}$. The polyphenol content was found to be the highest $922.80 \mathrm{mg}$ GAE $100 \mathrm{~g}^{-1}$ dry matter in the variety Rubina and the lowest in the variety Nantes (535.75 mg GAE $100 \mathrm{~g}^{-1}$ dry matter). After the pasteurization of juices, there was found the decrease of total carotenoids and polyphenols. Comparing the changes in carotenoids and polyphenols it can be concluded that changes in the content of total carotenoids due to heat treatment were more significant than in the content of total polyphenols.

\section{Acknowledgments}

This paper was supported by grant VEGA 1/0105/14 and KEGA 038SPU-4/2014

\section{References}

ARSCOTT, S. A. - TANUMIHARDJO, S. A. 2010. Carrots of many colors provide basic 
nutrition and bioavailable phytochemicals acting as a functional food. In Comprehensive Reviews in Food Science and Food Safety, vol. 9, no. 2, p. 223-239. DOI: 10.1111/j.1541-4337.2009.00103.x

AUGSPOLE, T. - RAKCEJEVA, L. - DUKALSKA, L. 2012. Changes of phenolic content and antiradical activity in hybrids of Nantes carrots during storage. In Cheminè technologija, vol. 62, no. 4, pp. 36-39. ISSN 1392-1231. http://dx.doi.org/10.5755/j01.ct.62.4.3119 BARANSKI, R. - ALLENDER, CH. - KLIMEK, CH. M. 2012. Towards better tasting and more nutritious carrots: Carotenoid and sugar content variation in carrot genetic resources. In Food research international, vol. 47, no. 2, pp. 182-187. ISSN 0963-9969. doi:10.1016/j.foodres.2011.05.006

BONGONI, R. - STIEGER, M. - DEKKER, M. - STEENBEKKERS, B. VERKER, R. 2014. Sensory and health properties of steamed and boiled carrots (Daucus carota ssp. sativus). In International Journal of Food Sciences and Nutrition, vol. 65, no. 7, pp. 809-815. doi: 10.3109/09637486.2014.931360

BUFLER, G. 2013. Accumulation and degradation of starch in carrot roots. In Scientia Horticulturae, vol. 150, p. 251-258. doi:10.1016/j. scienta.2012.11.022

CIEŚLIK, E. - GRĘDA, A. - ADAMUS, W. 2006. Contents of polyphenosls in fruit and vegetables. In Food chemistry, vol. 94, no. 1, pp. 135-142. doi:10.1016/j.foodchem.2004.11.015

FRANČÁKOVÁ, H. - FIKSELOVÁ, M. - MAREČEK, J. 2006. Karotenoidy a ich využitie $v$ potravinárstve. In Výživa a technologická kvalita rastlinných produktov a ich potravinárske využitie. Nitra : SPU, 2006, s. 29. ISBN 80-8069-780-9

GRASSMANN, J. - SCHNITZLER, W. - HABEGGER, R. 2007. Evaluation of different coloured carrot cultivars on antioxidative capacity based on their carotenoid and polyphenolic contents. In International Journal of Food Sciences and Nutrition, vol. 58, no. 8, pp. 603-611. DOI: 10.1080/09637480701359149

GONCALVES, E. M. - PINHEIRO, J. - ABREU M. - BRANDAO, T. R. S. - SILVA, C. L. M. 2010. Carrot (Daucus carota L.) peroxidase inactivation, phenolic content and physical changes kinetics due to blanching. In Journal of Food Engineering, vol. 97, pp. 574-581. http://dx.doi.org/10.1016/j.jfoodeng.2009.12.005

CHANTARO, P. - DEVAHASTIN, S. - CHIEWCHAN, N. 2008. Production of antioxidant high dietary fiber powder from carrot peels. In Food Science and Technology, vol. 41, no. 10, pp. 1987-1994. doi:10.1016/j.Iwt.2007.11.013

CHEN. H. E. - PENG, Y. H. - CHEN, H. B. 1996. Stability of carotenoids and vitamin A during storage of carrot juice. In Food chemistry, vol. 57, no. 4, pp. 497-503. doi:10.1016/S0308-8146(96)00008-8

JABBAR, S. - ABID, M. - HU, B. - HASHIM, M. M. - SAEEDUDDIN, M. - LEI, S. C. - ZENG, X. 2014. Influence of sonication and high hydrostatic pressure on the quality of carrot juice. In International Journal of Food Science and Technology, vol. 49, no. 11, pp. 2449 2457. DOI: $10.1111 /$ ijfs. 12567

JINTASATAPORN, O. - YUANGSOI, B. 2012. Stability of carotenoid diets during feed processing and under. In Molecules, vol. 17, pp. 5651-5660. doi:10.3390/molecules17055651

KRAMER, M. - MAKSYLEWICZ, K. A. - BARANSKI, R. - NOTHNAGEL, T. - CARLE, R. 2012. Effects of cultivation year and growing location on the phenolic profile of differently coloured carrot cultivars. In Journal of applied botany and food quality, vol. 85, no. 2, pp. 235-247.

KREUTZMANN, S. - CHRISTENSEN, L. P. - EDELENBOS, M. 2008. Investigation of bitterness in carrots (Daucus carota L.) based on quantitative chemical and sensory analyses. In Food Science and Technology, vol. 41, no. 2, pp. 193-205. doi:10.1016/j. Iwt.2007.02.024

KRINSKY, N. I. - JOHNSON, E. J. 2005. Carotenoid actions and their relation to health and disease. In Molecular aspects of medicine, vol. 26, no. 6, p. 459-516. DOI: 10.1016/j.mam.2005.10.001
LEJA, M., I. - KAMINSKA, M. - KRAMER, A. - MAKSYLEWICZ-KAUL, D. - KAMMERER, R. 2013. The content of phenolic compounds and radical scavenging activity varies with carrot origin and root coor. In Plant Foods for Human Nutrition, vol. 68, no. 2, pp. 163-170. doi: 10.1007/s11130-013-0351-3.

NOOKARAJU, A. - UPADHYAYA, C. P. - PANDEY, S. K. - YOUNG, K. E. HONG, S. J. - PARK, S. K. 2010. Molecular approaches for enhancing sweetness in fruits and vegetables. In Scientia Horticulturae, vol. 127, no. 1, pp. 1-15. doi:10.1016/j.scienta.2010.09.014

OLIVEIRA, V. E. - CASTRO, H. V. - EDWARDS, H. G. M. - OLIVEIRA, L. F. C. 2010. Carotenes and carotenoids in natural biological samples: A Raman spectroscopic analysis. In Journal of Raman Spectroscopy, vol. 41, no. 6, pp. 642-650. DOI: 10.1002/jrs.2493

SALARIYA, M. - ALI, M. - HUSSAIN, S. - JAMIL, K. 2009. Nutritional value of carrot juice as affected by different blanching media. In Food and Agriculture Organization of the United Nations, vol. 6, no. 1-2, pp. 95-98

SHARMA, D. K. - KARKI, S. - THAKUR, N. S. - ATTRI, S. 2012. Chemical composition, functional properties and processing of carrot. In Journal of Food Science Technology, vol. 1, no. 49, p. 22-32. doi: 10.1007/s13197-011-0310-7

SIMON, P. W. - WOLFF, X. Y. - PETERSON, C. E. - RUBATZKY, V. E. STRANDBERG, J. O. - BASSETT, M. J. 1989. High carotene mass carrot population. In Horticultural Science, vol. 24, pp. 174-175. ISSN 1805-9333.

SUN, T. - SIMON, P. W. - TANUMIHARDJO, S. A. 2009. Antioxidant phytochemicals and antioxidant capacity of biofortified carrots (Daucus carota L.) of various colors. In Journal of Agricultural and Food Chemistry, vol. 57, no. 10, pp. 4142-4147. doi: 10.1021/ jf9001044.

SINGLETON, V. L, ROSSI, J. A. 1965. Colorimetry of total phenolics with phosphomolybdic phosphotungstic acid reagents. In American Journal of Enology and Viticulture, vol. 16, no. 3, pp. 144-158.

SURLES, R. L. - WENG, N. - SIMON, P. W. - Tanumihardjo, S. A. 2004. Carotenoid profiles and consumer sensory evaluation of specialty carrots (Daucus carota, L.) of various colors. In Journal of Agriculture and Food Chemistry, vol. 52, no. 11, pp. 3417-3421.

ŠLOSÁR, M. - BARÁTOVÁ, S. - HEGEDÜSOVÁ, A. 2013. Karotenoidy ako významná súčast' l'udskej výživy. In Slovak journal of health sciences, vol. 4, no. 2, pp. 13-20. ISSN 1338-161X.

TEIXEIRA, L. J. Q. - ODRIOZOLA-SERRANO, I. - SOLIVA-FORTUNY, R. MOTA-RAMOS, A. - MARTÍN-BELLOSO, O. 2009. Comparative study on antioxidant properties of carrot juice stabilised by high-intensity pulsed electric fields or heat treatments In Food Science and Technology, vol. 89, no. 15, pp. 2636-2642. DOI: 10.1002/jsfa.3767

TIAN, C. - MA, T. - LUO, J. - ZHOU, R. - SUN, X. - MA, J. 2014. Influence of technical processing units on polyphenols and antioxidant capacity of carrot (Daucus carota L.) juice. In Food chemistry, vol. 141, no. 3, pp. 1637-1644. doi: 10.1016/j.foodchem.2013.04.121.

WANG H. - HU, X. - CHEM, F. - WU, J. - ZHANG, Z. - LIAO, X. - WANG, Z. 2006. Kinetics analysis of non-enzymatic browning in carrot juice concentrate during storage. In European Food Research and Technology, vol. 223, pp. 282-289. DOI 10.1007/s00217-005-0202-z YU, L. L. - ZHOU, K. K. - PARRY, J. 2005. Antioxidant properties of coldpressed black caraway, carrot, cranberry, and hemp seed oils. In Food Chemistry, vol. 91, no. 4, pp. 723-729. doi:10.1016/j. foodchem.2004.06.044

ZHANG, D. - HAMAUZU, Y. 2004. Phenolic compounds and their antioxidant properties in different tissues of carrots (Daucus carota L.). In Food, Agriculture and Environment, vol. 2, no.1, pp. 95-100. ISSN 1459-0263. 